Geosistemy perehodnykh zon = Geosystems of Transition Zones $/$ Геосистемы переходных зон

Content is available under the Creative Commons Attribution 4.0 International License (CC BY 4.0)

2020, vol. 4, No. 4, pp. 486-499

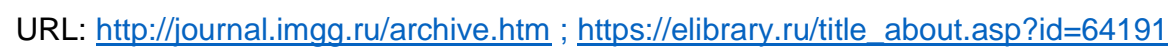

https://doi.org/10.30730/gtrz.2020.4.4.486-499

\title{
Seismoacoustic observations using molecular-electronic hydrophones on Sakhalin and the South Kuril Islands (Kunashir Island)
}

\author{
Dmitry V. Kostylev*1,2, Natalya V. Boginskaya ${ }^{2}$ \\ ${ }^{1}$ Sakhalin Branch, Geophysical Survey, Russian Academy of Sciences, Yuzhno-Sakhalinsk, Russia \\ 2 Institute of Marine Geology and Geophysics, FEB RAS, Yuzhno-Sakhalinsk, Russia \\ *E-mail: d.kostylev@imgg.ru
}

\section{Abstract PDF ENG Резюме PDF RUS $\quad$ Full text PDF RUS}

Abstract. The article presents the main characteristics and studies spectral and recording capabilities of experimental samples of three types of molecular-electronic hydrophones with different sizes of electrochemical converting cells, which were installed in the central part of the south of Sakhalin Island and on Kunashir Island (southern part of the Kuril ridge) at the end of 2018. A hydrophone on a new technological basis (with an increased sensor sensitivity relative to previously conducted studies) was approved on Kunashir Island. Equipment of this type was used for observations on the territory of the Sakhalin region for the first time. As a result of continuous seismoacoustic observations on Kunashir Island, in seven cases out of 35 studied (from May 1, 2019 to February 29,2020 ) earthquakes, a low-frequency anticipatory signal (LFAS) was detected, and all seven events had a depth of hypocenter of more than $80 \mathrm{~km}$. In the area of the Central Sakhalin fault, in addition to the possibility of registering the LFAS, spectral features in the recording of waveforms were studied for different conditions of instrument installation. It is shown that the influence of such atmospheric factor as wind load significantly affects hydrophones located in a shallow water body and a shallow open borehole. It is shown that the influence of such atmospheric factor as wind load significantly affects hydrophones located in a shallow water body and a shallow open borehole. However, molecular-electronic hydrophones have demonstrated the ability to fully record seismic events regardless of the installation conditions of the equipment.

\section{Keywords: \\ seismoacoustic observations, molecular-electronic hydrophone, spectral density, seismic events, low-frequency anticipatory signal}

For citation: Kostylev D.V., Boginskaya N.V. Seismoacoustic observations using molecular-electronic hydrophones on Sakhalin and the South Kuril Islands (Kunashir Island). Geosistemy perehodnykh zon = Geosystems of Transition Zones, 2020, vol. 4, no. 4, pp. 486-499. (In Russ., abstr. in Engl.). https://doi.org/10.30730/gtrz.2020.4.4.486-499

Для цитирования: Костылев Д.В., Богинская Н.В. Сейсмоакустические наблюдения с применением молекулярноэлектронных гидрофонов на Сахалине и южных Курильских островах (о. Кунашир). Геосистемы переходных зон, 2020, т. 4, № 4, c. 486-499. https://doi.org/10.30730/gtrz.2020.4.4.486-499

\section{References}

1. Borisov A.S., Borisov S.A. 2017. Estimation of parameters of hydroacoustic signals of high frequency geoacoustic emission within Central Sakhalin Fault area. Geosistemy perehodnykh zon = Geosystems of Transition Zones, (3): 64-70. (In Russ.). https://doi.org/10.30730/2541-8912.2017.1.3.064-070

2. Borisov A.S., Borisov S.A., Levin B.W., Sasorova E.V. 2012. Hydroacoustic observations of weak earthquakes in shallow waters of the Southern Kuril Islands. Geodynamics \& Tectonophysics, 3(2): 103-113. (In Russ.). https://doi.org/10.5800/gt-2012-3-20065

3. Borisov A.S., Borisov S.A., Gurskiy V.V. 2013. [Autonomous hydrophone seismic stations in the task of detailed seismic observations]. In.: IV nauch.-tekhnicheskaya konf. «Problemy kompleksnogo geofizicheskogo monitoringa Dal'nego Vostoka Rossii». 30 sent. - 4 okt. 2013, Petropavlovsk-Kamchatskiy [IV scientific and technical conference "Problems of complex geophysical monitoring of the Russian Far East”, 29 Sept. - 5 Oct. 2013, Petropavlovsk-Kamchatskiy]. PetropavlovskKamchatskiy: Kamchat. fil. Geofiz. sluzhby RAN [Petropavlovsk-Kamchatskiy: Kamchatka Branch of the Geophysical Survey of RAS], vol. 1: 313-317. URL: http://www.emsd.ru/conf2013lib/pdf/techn/Borisov_etc.pdf

4. Bugaev A.S., Antonov A.N., Agafonov B.M., Vergeles S.S., Dudkin P.V., Egorov E.V., Egorov I.V., Zhevnenko D.A., Zhabin S.N. et al. 2018. Measuring devices based on molecular-electronic transducers. J. of Communications Technology and Electronics, 63(12): 1339-1351. https://doi.org/10.1134/s1064226918110025

5. Demezhko D.Yu., Ryvkin D.G., Yurkov A.K., Dergatchev V.V., Korsuntsev V.G. 2009. Complex geothermal investigations in the borehole kun-1 (Kunashir Island). Pt. 1: Vertical temperature distribution, heat flow, topography and hydrogeology influence, diurnal wave propagation. Ural'skiy geofizicheskiy vestnik [Ural Geophysical Bulletin], 1(14): 18-29. (In Russ.).

6. Droznin D.V., Droznina S.Y. 2011. Interactive DIMAS program for processing seismic signals. Seismic Instruments, 47(3): 215224. https://doi.org/10.3103/s0747923911030054 
7. Zaytsev D.L., Egorov E.V., Avdyukhina S.Yu., Ryzhkov M.A. 2019. Molekulyarno-elektronnyy gidrofon [Molecular electronic hydrophone]: patent RU 2678503 C1. № 2017146249; appl. 27.12.2017; publ. 29.01.2019. (In Russ.).

8. Kamenev P.A., Kostylev D.V., Boginskaya N.V., Zakupin A.S. 2019. Geophysical surveys in the southern part of the Central Sakhalin Fault based on new integrated network. Geosistemy perehodnykh zon = Geosystems of Transition Zones, 3(4): 390402. (In Russ.). https://doi.org/10.30730/2541-8912.2019.3.4.390-402

9. Kostylev D.V., Boginskaya N.V. 2019. [On the experience of using molecular-electronic seismic sensors on the Sakhalin and South Kuriles]. In: VII nauch.-tekhnich. konf. "Problemy kompleksnogo geofizicheskogo monitoringa Dal'nego Vostoka Rossii», 29 sent. - 5 okt. 2019, Petropavlovsk-Kamchatskiy [VII scientific and technical conference "Problems of complex geophysical monitoring of the Russian Far East", 29 Sept. - 5 Oct. 2019]. Petropavlovsk-Kamchatskiy: KF FITs EGS RAN [KB FRC UGS RAS], vol. 1: 455-458. (In Russ.). URL: http://www.emsd.ru/conf2019lib/pdf/techn/kostilev.pdf

10. Sasorova E.V. 2005. Osobennosti raznomasshtabnykh prostranstvenno-vremennykh proyavleniy seysmicheskogo protsessa $v$ Tikhookeanskom regione: nablyudeniya, statistika, modelirovanie [Features of different-scale space-time manifestations of the seismic process in the Pacific region: observations, statistics, simulation]: [dissertation of doctor of physical and mathematical sciences]. Moscow, P.P. Shirshov Institute of Oceanology, RAS, 342 p. (In Russ.).

11. Semenova E.P., Kostylev D.V., Mikhailov V.I., Parshina I.A., Fercheva V.N. 2018. Evaluation seismicity in Southern Sakhalin with the use of the method SOUS'09. Geosistemy perehodnykh zon = Geosystems of Transition Zones, 2(3): 191-195. (In Russ.). https://doi.org/10.30730/2541-8912.2018.2.3.191-195

12. Huang H., Agafonov V., Yu H. 2013. Molecular electric transducers as motion sensors: a review. Sensors, 13(4): 4581-4597. https://doi.org/10.3390/s130404581

13. Kostylev D.V., Bogomolov L.M., Boginskaya N.V. 2019. About seismic observations on Sakhalin with the use of molecularelectronic seismic sensors of new type. In: IOP Conf. Series: Earth and Environmental Science, 324(012009). https://doi.org/10.1088/1755-1315/324/1/012009

14. Zaitsev D.L., Avdyukhina S.Y., Ryzhkov M.A., Evseev I., Egorov E.V., Agafonov V.M. 2018. Frequency response and selfnoise of the met hydrophone. J. of Sensors and Sensor Systems, 7(2): 443-452. https://doi. org/10.5194/jsss-7-443-2018

15. Zaitsev D., Egorov E., Ryzhkov M., Velichko G., Gulenko V. 2019. Low-frequency, low-noise molecular-electronic hydrophone for offshore and transit zone seismic exploration. In: 19-th International Multidisciplinary Scientific GeoConference SGEM, 28 June - 7 July 2019, Albena, Bulgaria: Conf. proceedings, 1: 961-968. 